\title{
Palliative care for children and young people with stage 5 chronic kidney disease
}

\author{
Finella Craig ${ }^{1}$ (D) $\cdot$ Ellen M. Henderson ${ }^{2} \cdot$ Bhumik Patel $^{3} \cdot$ Fliss E. M. Murtagh $^{4} \cdot$ Myra Bluebond-Langner $^{2,5}$
}

Received: 12 January 2021 / Revised: 3 March 2021 / Accepted: 15 March 2021 / Published online: 14 May 2021

(C) The Authors 2021, corrected publication 2021

\begin{abstract}
Death from stage 5 chronic kidney disease (CKD 5) in childhood or adolescence is rare, but something that all paediatric renal physicians and most paediatricians will encounter. In this paper, we present the literature on three key areas of palliative care practice essential to good clinical management: shared decision-making, advance care planning, and symptom management, with particular reference to CKD 5 where kidney transplant is not an option and where a decision has been made to withdraw or withhold dialysis. Some areas of care, particularly with regard to symptom management, have not been well-studied in children and young people (CYP) with CKD 5 and recommendations with regard to drug choice and dose modification are based on adult literature, known pharmacokinetics, and clinical experience.
\end{abstract}

Keywords Stage 5 chronic kidney disease (CKD 5) $\cdot$ Kidney failure $\cdot$ Conservative management $\cdot$ Palliative care $\cdot$ Symptom management $\cdot$ Advance care planning

\section{Introduction}

The Renal Physicians Association identifies two groups of children and young people (CYP) who may be considered unsuitable for dialysis and transplant:

1. Those who, often due to complex multi-system disease or co-morbidity, would not be suitable candidates for transplant and where dialysis is considered a significant burden without medium- to long-term benefit.

Finella Craig

finella.craig@gosh.nhs.uk

1 The Louis Dundas Centre for Children's Palliative Care, Great Ormond Street Hospital for Children NHS Foundation Trust, Great Ormond Street, London WC1N 3JH, UK

2 The Louis Dundas Centre for Children's Palliative Care, UCL Great Ormond Street Institute of Child Health, 30 Guilford Street, London, UK

3 The Louis Dundas Centre for Children's Palliative Care and Dept. Pharmacy, Great Ormond Street Hospital for Children NHS Foundation Trust, London, UK

4 Wolfson Palliative Care Research Centre, Hull York Medical School, University of Hull, Hull, UK

5 Rutgers University, Camden, NJ, USA
2. Those who have embarked on dialysis, but for whom transplant is no longer (or has never been) an option, where the burden of dialysis has become too great in relation to potential benefit [1].

The Renal Physicians Association has also published guidance for shared decision-making regarding the withholding and withdrawing of dialysis in paediatric patients. These recommendations include:

1. Forgoing dialysis if initiating or continuing dialysis is deemed to be harmful, of no benefit, or merely prolongs a child's dying process.

2. Consider forgoing dialysis in a patient with a terminal illness whose long-term prognosis is poor if the patient and family agree with the physician that dialysis would not be of benefit or the burdens would outweigh the benefit.

3. Consider the use of a time-limited trial of dialysis in neonates, infants, children, and adolescents with acute kidney injury (AKI) or stage 5 chronic kidney disease (CKD 5) to allow for the assessment of extent of recovery from an underlying disorder.

4. Develop a palliative care plan for all paediatric patients with CKD 5 from the time of diagnosis and for children with AKI who forgo dialysis [1]. 
This article focuses on the palliative management of CYP with CKD 5 where kidney transplant is not an option and where a decision has been made to withdraw or withhold dialysis. The recommendations made are based on published literature combined with the clinical experience of a palliative care team working in a large tertiary centre.

\section{Shared decision-making and advance care planning}

When addressing significant kidney disease, professionals must have an open and honest, age and developmentally appropriate approach to communicating with CYP, working in partnership with parents. Studies indicate that any approach to discussion of the illness or management of care and treatment should reflect all individuals, especially the CYP's preference for degree and timing of disclosure [2-4]. In circumstances where withholding or withdrawing dialysis is being considered, discussions should involve a palliative care specialist, where available, in addition to the renal physician, so the family can be given a full understanding of all the options for care [5]. In order to best support parental and CYP decision-making, it is important that they receive information about life on dialysis, or with a transplant, and the feasibility and likelihood of success [6], as well as what palliative management will involve, including what symptoms to expect, and where and how these can be managed. Attention should be given to the family's thoughts on the impact of any intervention, on the child, their family life, and on their child's prognosis, as well as what they consider the likely outcome, what they would like to see happen, and what they think will happen [7].

Enabling families to choose where and how they spend their time is a key component of palliative care. Some may choose a very hospital-focused approach to end of life care, but others may want most of their care to be at home or in a children's hospice. If choosing to be at home, families will need clear guidance with regard to symptom assessment, management, and medication administration, and will require access to appropriate medication and equipment, 24-h palliative care, and the support of teams in their own community (e.g. children's community nurses, family doctor, paediatrician). After death, it may be possible for ongoing care to be provided at home or in a hospice, regardless of where the CYP died, as an alternative to a funeral home or mortuary. If families choose for the CYP to move after death, transport plans should be put in place in advance.

The presence of both palliative care and renal teams for these discussions ensures continuity of care and joined-up work, preventing families from feeling that the renal team has 'given up' on their child. Both teams present together assures the family in a concrete and substantive manner that the child and family will not be abandoned, often a major concern of parents [7].

These discussions are part of the advance care planning process: a process in which the parents/CYP and clinical teams discuss what the future may look like, the options available, and their priorities and goals [8]. It allows consideration of medical interventions, resuscitation, place of death, and care after death as well as wishes for life [8]. Decisions made and wishes voiced should be clearly recorded, for example in an advance care plan document such as the Children and Young Person's Advance Care Plan (www.cypacp.uk), and shared with relevant professionals.

It is important to recognise that parents/CYP often strive to keep their options open [8] and responses like 'I'll decide at the time' are not atypical. Advance care planning discussions will usually, and appropriately, require a series of conversations over time, with plans reviewed and adapted as the CYP's condition changes.

\section{Symptom management}

CKD 5 is associated with a significant symptom burden. One adult study reported over $50 \%$ of adult patients experienced lack of energy, itch, drowsiness, dyspnoea, poor concentration, pain, poor appetite, swelling of arms/legs, and dry mouth [9]. A study in children with CKD 5 reported pain in over 50\% and a high incidence (20-40\%) of other symptoms, including fatigue, nausea, dyspnoea, agitation, and pruritis [10].

\section{Prevention of symptoms}

Consideration should be given to management of blood pressure, fluid balance, anaemia, acidosis, hyperkalaemia, magnesium, and phosphate. Any interventions require regular review, incorporating the views of the CYP and parents, to avoid continuing those that have no or minimal benefit, or where the burden (such as hospital attendance) outweighs perceived benefit.

\section{Holistic management}

A holistic approach to symptom management is essential, addressing psychological, social, and spiritual factors that influence symptom experience and response. Nonpharmacological approaches such as massage, relaxation techniques, and guided imagery should be used both alongside or in place of medication. A psychologist and/or Child Life specialist should be part of the team caring for the CYP and family and CYP should have opportunities to explore and express their understanding, fears, and wishes through other modalities such as art, music, or drama therapy. 


\section{Medication dosing}

CKD 5 significantly alters the effects of medications, promoting potential toxicity [11]. Estimation of glomerular filtration rates and creatinine clearance are the most common tools used when determining appropriate dosing. However, this does not account for the influence of tubular secretion or for the effects of CKD 5 on pharmacokinetic variables such as absorption, distribution, metabolism, and elimination [12].

Prescribers must be aware of potential toxicity and prescribe according to a recognised formulary, such as the Association for Paediatric Palliative Medicine Drug Formulary [13], the British National Formulary for Children $(\mathrm{BNF})$, or other relevant local or national formularies, and make the recommended dose adjustments.

Recommendations in this article are based on a combination of existing evidence for dose modification, known pharmacokinetic parameters, and clinical experience.

\section{Pain (Table 1)}

Pain is a common, often underestimated, symptom in CKD 5 $[10,31]$ and may include musculoskeletal, neuropathic, and bone pain, as well as discomfort due to a renal mass or ascites.

Paracetamol is the non-opioid analgesic of choice. Nonsteroidal anti-inflammatory drugs (NSAIDs) should be avoided, unless the benefits of therapy are deemed to outweigh risks.

Opioids have been poorly studied within paediatrics, particularly in CKD 5. Fentanyl, alfentanyl, and methadone appear to be the safest opioids, due to hepatic metabolism to inactive metabolites [23, 32]. Fentanyl and alfentanyl uses are limited by the lack of appropriate enteral formulations and clinical experience. The complex pharmacokinetic profile of methadone plus lack of experience outside specialist units makes methadone a less than ideal choice. Hydromorphone, not commonly used in the UK, is not recommended due to the potential accumulation of neurotoxic metabolites [23]. However, we acknowledge that where clinicians are experienced in the use of hydromorphone it could be used cautiously on an 'as needed' basis.

Despite many reference sources suggesting the avoidance of oxycodone or morphine, there is evidence to suggest careful introduction and dosing may be safe and effective [14, 18], particularly following bolus dose administration. Morphine and oxycodone are therefore generally the opioids of choice in paediatric CKD 5, particularly for enteral use. We recommend increasing the dosing interval rather than reducing the dose, to ensure adequate analgesia, but with sufficient time for clearance to reduce accumulation. Risk of accumulation increases with repeated doses; in this instance, dose reduction may also be needed but should be titrated carefully to ensure good analgesic effect.
Peripheral neuropathy and neuropathic pain are not unusual in CKD 5 [33] but most medications commonly used to treat neuropathic pain should be avoided or used at significantly reduced doses.

Recommendations for management are given in Table 1.

\section{Agitation (Table 2)}

Agitation is often attributed to the accumulation of toxic metabolites, but factors such as pain, breathlessness, fear, and drug toxicity should be considered. Where medication is required, cautious use of haloperidol with dose reduction, or levomepromazine with slow careful dose titration, is likely to be the best option, although midazolam may have a role in some situations.

\section{Dyspnoea (Table 2)}

Dyspnoea is most frequently due to infection, anaemia, or pulmonary oedema. Interventions directed at treating an underlying cause may be appropriate, alongside symptomatic management. The benefits of fluid restriction may be limited and an unnecessary burden, and diuretics may have limited response. Blood transfusion can be burdensome and exacerbate fluid overload. For symptomatic relief, nonpharmacological interventions, such as a hand-held fan directed at the face, can be effective [45]. An opioid should be the first-choice medication, given at $25-50 \%$ of the dose used for pain management [46] on an 'as needed' basis. Using midazolam alongside an opioid may give additional benefit [47], but this should be used cautiously.

\section{Nausea and vomiting (Table 2)}

Nausea and vomiting can result from raised urea levels and metabolic disturbance, but also gastrointestinal fluid retention, gastric stasis, reflux, pain, and anxiety. Allowing CYP to eat 'little and often' or reducing nasogastric/gastrostomy feed volumes may bring relief without recourse to medication. Firstchoice anti-emetics are haloperidol, with dose reduction, or levomepromazine, starting at a low dose and titrating up slowly [40].

Metoclopramide is an option where gastric stasis is a factor, but accumulation may occur in kidney impairment so dose reduction is required $[40,41]$. Ondansetron is safe for use, without dose modification.

\section{Pruritis (Table 2)}

Regular skin care, using emollients, is essential. Phosphate binders can be effective if phosphate levels are high. In uraemic itch, antihistamines may have little benefit and lowdose gabapentinoids are likely to be preferable [48]. The 
Table 1 Summary of pain management in stage 5 chronic kidney disease (CKD 5)

\begin{tabular}{|c|c|c|c|}
\hline Drug & $\begin{array}{l}\text { Accumulation } \\
\text { in CKD } 5\end{array}$ & Recommendation & Pharmacology \\
\hline Alfentanyl & No & $\begin{array}{l}\text { Safe without dose modification but use with caution. } \\
\text { Start at low dose and slowly titrate to effect, with } \\
\text { close monitoring. } \\
\text { Alterations in protein binding due to uraemia or reduced } \\
\text { plasma protein may lead to increases in unbound } \\
\text { fraction and CNS toxicity }\end{array}$ & $\begin{array}{l}\text { Hepatic metabolism to inactive metabolites that are } \\
\text { cleared renally. } 90 \% \text { protein bound with only } \\
\text { unbound fraction able to cross into CNS. }\end{array}$ \\
\hline Amitriptyline & Possible & $\begin{array}{l}\text { Avoid } \\
\text { Accumulation of metabolites may precipitate toxicity, } \\
\text { including cardiac arrhythmias }[14,15] .\end{array}$ & $\begin{array}{l}\text { 1st pass metabolism to nortriptyline, a more potent } \\
\text { metabolite that is renally excreted [14-17]. }\end{array}$ \\
\hline Fentanyl & Possible & $\begin{array}{l}\text { Safe without dose modification but may accumulate } \\
\text { over time-use with caution } \\
\text { Start at low dose and slowly titrate with close } \\
\text { monitoring. Potential for prolongation of half-life and } \\
\text { reduced clearance [18]. }\end{array}$ & $\begin{array}{l}\text { Hepatic metabolism to inactive metabolites. } 10 \% \text { of } \\
\text { parent drug excreted unchanged. Excreted in urine } \\
\text { and faeces [18]. }\end{array}$ \\
\hline $\begin{array}{l}\text { Gabapentinoids: } \\
\text { gabapentin and } \\
\text { pregabalin }\end{array}$ & Yes & $\begin{array}{l}\text { For all routes, use with caution, starting at } 50 \% \text { dose } \\
\text { with either once daily or alternate day dosing. When } \\
\text { increasing the dose, consider maintaining extended } \\
\text { dosing interval, allowing sufficient time for clearance. }\end{array}$ & $\begin{array}{l}\text { Renally cleared and excreted unchanged in the urine, so } \\
\text { potential for prolonged clearance in CKD } 5 \text { [19-22]. }\end{array}$ \\
\hline Hydromorphone & Yes & $\begin{array}{l}\text { Not recommended. However, experienced clinicians } \\
\text { may choose to use cautiously, on an 'as needed' basis, } \\
\text { starting at the lowest recommended dose. }\end{array}$ & $\begin{array}{l}\text { Hepatic metabolism to hydromorphone-3-glucoronide, } \\
\text { which is excreted in the urine [23]. } \\
\text { Potential for accumulation and neurotoxicity. }\end{array}$ \\
\hline Ketamine & Yes & $\begin{array}{l}\text { Start at lowest usual recommended dose and titrate } \\
\text { according to response and toxicity. } \\
\text { Active metabolites may accumulate but not thought to } \\
\text { have significant clinical impact }[24,25] \text {. }\end{array}$ & $\begin{array}{l}\text { Hepatic metabolism to norketamine, an active } \\
\text { metabolite with } 20-30 \% \text { the potency of ketamine [ } 24 \text {, } \\
25] \text {. } \\
\text { Final clearance is in the urine and in bile [26]. }\end{array}$ \\
\hline Methadone & Possible & $\begin{array}{l}\text { Safe but for use with extreme caution and close } \\
\text { monitoring, only under specialist supervision. } \\
\text { Start at the lowest recommended dose and slowly titrate } \\
\text { with close monitoring. }\end{array}$ & $\begin{array}{l}\text { Approximately } 20-50 \% \text { excreted in urine as metabolites } \\
\text { or unchanged methadone }[18,23] \text {. Protein binding to } \\
\text { alphal-acid glycoprotein may be up-regulated, po- } \\
\text { tentially prolonging drug half-life }[18,27] \text {. }\end{array}$ \\
\hline
\end{tabular}

Time to steady state, analgesic efficacy, and toxicity unpredictable.

\begin{tabular}{|c|c|c|}
\hline Morphine & Yes & $\begin{array}{l}\text { Use with caution on an 'as needed' basis, starting at } \\
\text { lowest recommended dose. Increase dose interval } \\
\text { rather than reducing the dose, to ensure adequate } \\
\text { analgesia with sufficient time for clearance. Risk of } \\
\text { accumulation with repeated doses may require dose } \\
\text { reduction, but titrate carefully to ensure adequate } \\
\text { analgesia. } \\
\text { Extreme caution if converting to long-acting oral prep- } \\
\text { aration. } \\
\text { Where continuous infusion needed, consider conversior } \\
\text { to another opioid with safer renal profile, e.g. } \\
\text { fentanyl. }\end{array}$ \\
\hline $\begin{array}{l}\text { Non-steroid } \\
\text { anti-- } \\
\text { inflammatory } \\
\text { drugs }\end{array}$ & No & $\begin{array}{l}\text { Avoid - unsafe for use unless no other alternatives. } \\
\text { Risk of worsening kidney function }[27] \text { and bleeding } \\
\text { due to platelet dysfunction }[15,27,28] \text {. }\end{array}$ \\
\hline Oxycodone & Yes & $\begin{array}{l}\text { Use with caution on an 'as needed basis', starting at } \\
\text { lowest dose and titrating slowly. } \\
\text { Extreme caution if converting to long-acting prepara- } \\
\text { tions. } \\
\text { Consider switch to fentanyl if continuous infusion } \\
\text { needed. }\end{array}$ \\
\hline
\end{tabular}

Metabolites and approximately $10 \%$ of parent drug (unchanged) rely on renal clearance [23].

Risk of accumulation of active metabolites which may potentiate CNS effects [14, 23].

Hepatic metabolism to inactive metabolites with less than $10 \%$ of parent drug excreted unchanged in urine.

No evidence to suggest safety of one NSAID over another [15].

Hepatic metabolism to active metabolites, one of which (noroxycodone) has an affinity for the opioid receptor $40 \times$ greater than oxycodone. Potential for accumulation of metabolites and parent drug in renal impairment but not thought clinically significant [18]. 
Table 1 (continued)

\begin{tabular}{llll}
\hline Drug & $\begin{array}{l}\text { Accumulation } \\
\text { in CKD 5 }\end{array}$ & Recommendation & Pharmacology \\
\hline Paracetamol & Possible & $\begin{array}{c}\text { Normal dosing but maintain a minimum of a 6-h interval } \\
\text { between doses. } \\
\text { Potential for reduced excretion of metabolites, though } \\
\text { half-life of parent drug remains unaltered [30]. }\end{array}$ & $\begin{array}{c}\text { metabolites [28, 29]. Metabolites plus less than 10\% } \\
\text { of parent drug (unchanged) excreted in urine. }\end{array}$ \\
\hline
\end{tabular}

benefit of ondansetron is negligible [49]. Amongst the less frequently used drugs, there is conflicting evidence for the role of naltrexone $[50,51]$ but evidence for the benefit of thalidomide [52], which can be used without dose adjustment, though experience of use in paediatrics is extremely limited [53].

\section{Fatigue}

Fatigue may be due to or exacerbated by anaemia. For some, regular transfusion may be appropriate, but this needs to be considered against the burden of hospitalisation and need for intravenous access, as well as the risk of fluid overload exacerbating dyspnoea. Maintaining haemoglobin with an erythropoiesis stimulator can be a helpful compromise, but will have limited benefit in advancing disease. Practical approaches to managing fatigue should not be overlooked. Maintaining a good day/night pattern, with activities during the day and a good bedtime routine, is important. Good management of symptoms will aid undisturbed sleep, as well as addressing anxieties and fears, which can often be exacerbated overnight.

\section{Secretions (Table 2)}

As conscious levels reduce, CYP become less able to manage oral secretions. Hyoscine hydrobromide crosses the bloodbrain barrier and may cause increased drowsiness, delirium, or paradoxical agitation, particularly in CKD 5 where uraemia increases the permeability of the blood-brain barrier [40]. Glycopyrronium (glycopyrrolate) is generally the drug of choice, with dose reduction required and careful dose titration [44]. Hyoscine butylbromide can also be used and is safe for use in CKD 5 without dose reduction.

\section{Key summary points}

1. Decisions to commence or forgo dialysis and transplant should be made jointly between the clinical teams, parents, and, where appropriate, the CYP.

2. Advance care planning is the process through which clinicians, parents, and CYP discuss and document their priorities and goals for future care. It should include, but not be limited to, agreement of treatment limitations.

3. CKD 5 is associated with a significant symptom burden that includes pain, agitation, and dyspnoea. The prevalence of physical and psychological symptoms may be greater than those in patients with advanced cancer.

4. CKD 5 significantly alters the effects of medications, often promoting toxicity; however, information regarding the extent of dose reduction for many drugs is limited. It is essential that prescribers are aware of potential toxicity, prescribe using a recognised formulary, observe patients closely, and adjust doses cautiously (considering both reducing doses and increasing dosing intervals) in response to effect and observed toxicity.

\section{Multiple choice questions (answers are provided following the reference list)}

1. Advance care planning discussions

a) Should result in an agreement regarding resuscitation and limitations of treatment.

b) Are often a series of conversations over a period of time and decisions may change.

c) Must be led by a palliative care physician.

d) Should only involve the CYP in exceptional circumstances

2. When involving CYP in decision-making

a) Child/young person's age is the most important consideration.

b) Clinician should meet with the child/young person alone.

c) Child/young person's wishes should take precedence over the wishes of parents.

d) Child/young person should determine degree and timing of disclosure of information about care, treatment, condition, and prognosis.

3. When selecting an opioid for pain management in CKD 5

a) Morphine should be avoided due to accumulation.

b) Oxycodone is a good option for a long-acting opioid. 
Table 2 Summary of symptom management medication recommendations

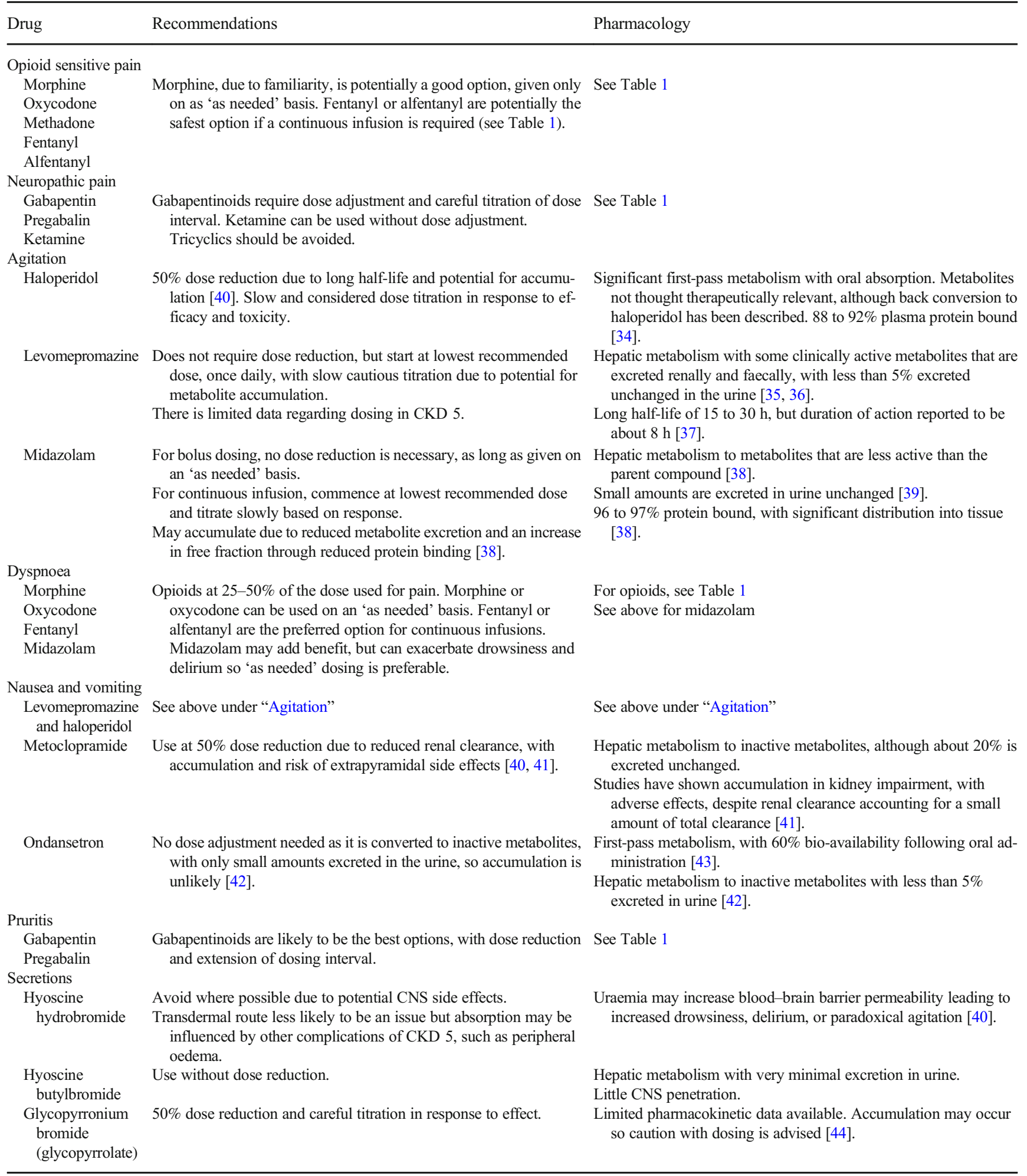


c) Fentanyl or alfentanyl are the preferred option for a continuous infusion.

d) The opioid dosing interval should generally be reduced.

4. When treating neuropathic pain in CKD 5

a) Ketamine should be used cautiously, with dose reduction.

b) Gabapentin is safe to use without dose reduction.

c) Tricyclics can be used cautiously.

d) Pregabalin can be used but with dose reduction and a long dosing interval.

5. The following medications can be used to manage agitation

a) Haloperidol at 50\% dose reduction.

b) Levomepromazine at lowest recommended starting dose.

c) Bolus doses of midazolam, without dose reduction.

d) All of the above.

Funding Ellen Henderson's post is supported by a programme grant to the Louis Dundas Centre for Children's Palliative Care from Great Ormond Street Hospital Children's Charity.

Myra Bluebond-Langner's post is supported by funding from TheTrue Colours Trust.

Fliss Murtagh is a National Institute for Health Research (NIHR) Senior Investigator.

Bhumik Patel's post is supported by a programme grant to the Louis Dundas Centre for Children's Palliative Care from Great Ormond Hospital Children's Charity.

All researche at Great Ormond Street Hospital NHS Foundation Trust is made possible by the NIHR Great Ormond Street Hospital Biomedical Research Centre.

\section{Declarations}

Conflict of interest The authors declare no competing interests.

Disclaimer The views expressed in this article are those of the author(s) and not necessarily those of the NIHR, the Department of Health and Social Care, the NHS, or the Department of Health.

Open Access This article is licensed under a Creative Commons Attribution 4.0 International License, which permits use, sharing, adaptation, distribution and reproduction in any medium or format, as long as you give appropriate credit to the original author(s) and the source, provide a link to the Creative Commons licence, and indicate if changes were made. The images or other third party material in this article are included in the article's Creative Commons licence, unless indicated otherwise in a credit line to the material. If material is not included in the article's Creative Commons licence and your intended use is not permitted by statutory regulation or exceeds the permitted use, you will need to obtain permission directly from the copyright holder. To view a copy of this licence, visit http://creativecommons.org/licenses/by/4.0/.

\section{References}

1. Renal Physicians Association (ed) (2010) Shared decision-making in the appropriate initiation of and withdrawal from dialysis, 2nd edn. Renal Physicians Association, Rockville

2. Sisk BA, Bluebond-Langner M, Wiener L, Mack J, Wolfe J (2016) Prognostic disclosures to children: a historical perspective. Pediatrics 138:e20161278. https://doi.org/10.1542/peds.2016-1278

3. Day E, Jones L, Langner R, Bluebond-Langner M (2016) Current understanding of decision-making in adolescents with cancer: a narrative systematic review. Palliat Med 30:920-934. https://doi. org/10.1177/0269216316648072

4. Sisk BA, Kang TI, Mack JW (2017) Prognostic disclosures over time: parental preferences and physician practices. Cancer 123: 4031-4038. https://doi.org/10.1002/cncr.30716

5. Bluebond-Langner M, Belasco JB, Goldman A, Belasco C (2007) Understanding parents' approaches to care and treatment of children with cancer when standard therapy has failed. J Clin Oncol 25: 2414-2419. https://doi.org/10.1200/jco.2006.08.7759

6. Dionne JM, d'Agincourt-Canning L (2015) Sustaining life or prolonging dying? Appropriate choice of conservative care for children in end-stage renal disease: an ethical framework. Pediatr Nephrol 30:1761-1769. https://doi.org/10.1007/s00467-0142977-2

7. Bluebond-Langner M, Hargrave D, Henderson EM, Langner R (2017) 'I have to live with the decisions I make': laying a foundation for decision making for children with life-limiting conditions and life-threatening illnesses. Arch Dis Child 102:468-471. https:// doi.org/10.1136/archdischild-2015-310345

8. Beecham E, Oostendorp L, Crocker J, Kelly P, Dinsdale A, Hemsley J, Russell J, Jones L, Bluebond-Langner M (2017) Keeping all options open: parents' approaches to advance care planning. Health Expect 20:675-684. https://doi.org/10.1111/hex. 12500

9. Murtagh FE, Addington-Hall J, Edmonds P, Donohoe P, Carey I, Jenkins K, Higginson IJ (2010) Symptoms in the month before death for stage 5 chronic kidney disease patients managed without dialysis. J Pain Symptom Manag 40:342-352. https://doi.org/10. 1016/j.jpainsymman.2010.01

10. Keefer P, Lehmann K, Shanley M, Woloszyk T, Khang E, Luckritz K, Saul D (2017) Single-centre experience providing palliative care to pediatric patients with end-stage renal disease. J Palliat Med 20: 845-849

11. Doogue MP, Polasek TM (2011) Drug dosing in renal disease. Clin Biochem Rev 32:69-73

12. Fudin J, Persico A, Wegrzyn E (2017) Pain management in endstage renal disease. https://www.pharmacytimes.com/view/painmanagement-in-end-stage-renal-disease

13. The Association of Paediatric Palliative Medicine (2015) The association of paediatric palliative medicine master formulary. The Association of Paediatric Palliative Medicine, Loughborough

14. Sakata RK, Nunes MHG (2014) Analgesic use for kidney failure. Revista Dor 15:224-229

15. Murphy EJ (2005) Acute pain management pharmacology for the patient with concurrent renal or hepatic disease. Anaesth Intensive Care 33:311-322

16. Asley C, Dunleavy A (2014) The renal drug database. CRC Press, Taylor \& Francis Group, Oxon

17. Lawson K (2017) A brief review of the pharmacology of amitriptyline and clinical outcomes in treating fibromyalgia. Biomedicines 24:1-12

18. Atkinson TJ, Fudin J, Wegrzyn LE, Bettinger JJ (2014) Dialysis, opioids, and pain management: where's the evidence. Pract Pain Manag:49-57 
19. Buck ML (2016) Gabapentin use in postoperative and neuropathic pain in children. Pediatr Pharmacother 22:1-4

20. Zand L, McKian KP, Qian Q (2010) Gabapentin toxicity in patients with chronic kidney disease: a preventable cause of morbidity. Am J Med 123:367-373. https://doi.org/10.1016/j.amjmed.2009.09. 030

21. Randinitis EJ, Posvar EL, Alvey CW, Sedman AJ, Cook JA, Bockbrader HN (2003) Pharmacokinetics of pregabalin in subjects with various degrees of renal function. J Clin Pharmacol 43:277283. https://doi.org/10.1177/0091270003251119

22. Landefeld CS, Steinman MA (2009) The Neurontin Legacymarketing through misinformation and manipulation. $\mathrm{N}$ Engl $\mathrm{J}$ Med 360:103-106

23. Dean M (2004) Opioids in renal failure and dialysis patients. J Pain Symptom Manag 28:497-504. https://doi.org/10.1016/j. jpainsymman.2004.02.021

24. Peltoniemi MA, Hagelberg NM, Olkkola KT, Saari TI (2016) Ketamine: a review of the clinical pharmacokinetics and pharmacodynamics in anesthesia and pain therapy. Clin Pharmacokinet 55: 1059-1077

25. Mion G, Villevieille T (2013) Ketamine pharmacology: an update (Pharmacodynamics \& Molecular Aspects, Recent Findings). CNS Neurosci Ther 19:370-380

26. Dinis-Oliveira RJ (2017) Metabolism and metabolomics of ketamine: a toxicological approach. Forensic Sci Res 2:2-10

27. Pham PC, Khaing K, Sievers TM, Pham PM, Miller JM, Pham SV, Pham PA, Pham PT (2017) 2017 update on pain management in patients with chronic kidney disease. Clin Kidney J 10:688-697

28. Rainsford KD (2009) Ibuprofen: pharmacology, efficacy and safety. Inflammopharmacology 17:275-342

29. Bushra R, Aslam N (2010) An overview of clinical pharmacology of ibuprofen. Oman Med J 25:155-161

30. Bannwarth B, Pehourcq F (2003) Pharmacological rationale for clinical use of paracetamol: pharmacokinetic and pharmacodynamic issues. Drugs 63(SpecNo 2):1-9

31. Conill C, Verger E, Henríquez I, Saiz N, Espier M, Lugo F, Garrigos A (1997) Symptom prevalence in the last week of life. J Pain Symptom Manag 14:328-331. https://doi.org/10.1016/S08853924(97)00263-7

32. Murtagh FEM, Chai M-O, Donohoe P, Edmonds PM, Higginson IJ (2007) The use of opioid analgesia in end-stage renal disease patients managed without dialysis. J Pain Palliat Care Pharmacother 21:5-16. https://doi.org/10.1080/J354v21n02_03

33. O'Connor NR, Corcoran AM (2012) End-stage renal disease: symptom management and advance care planning. Am Fam Physician 85:705-710

34. Brayfield A (ed) (2017) Martindale: the complete drug reference, 39th edn. London, Pharmaceutical Press

35. Taylor G, Houston JB, Shaffer J, Mawer G (1983) Pharmacokinetics of promethazine and its sulphoxide metabolite after intravenous and oral administration to man. Br J Clin Pharmacol 15:287-293

36. Choo H-YP, Shin YO, Park J (1990) Study of the metabolism of phenothiazines: determination of $\mathrm{N}$-demethylated phenothiazines in urine. J Anal Toxicol 14:116-119

37. Dietz I, Schmitz A, Lampey I, Schulz C (2013) Evidence for the use of levomepromazine for symptom control in the palliative care setting: a systematic review. BMC Palliat Care 12:1-11

38. Reves JG, Fragen RJ, Vinik R, Greenblatt DJ (1985) Midazolam: pharmacology and uses. Anesthesiology 62:310-324
39. Pacifici GM (2014) Clinical pharmacology of midazolam in neonates and children: effect of disease - a review. Int J Pediatr 2014: 309342

40. Douglas C, Murtagh F, Chambers E, Howse M, Ellershaw J (2009) Symptom management for the adult patient dying with advanced chronic kidney disease: a review of the literature and development of evidence-based guidelines by a United Kingdom Expert Consensus Group. Palliat Med 23:103-110. https://doi.org/10. 1177/0269216308100247

41. Bateman DN (1983) Clinical pharmacokinetics of metoclopramide. Clin Pharmacokinet 8:523-529

42. Pritchard FJ (1992) Ondansetron metabolism and pharmacokinetics. Semin Oncol 19(4 Suppl 10):9-15

43. Roila F, Favero AD (1995) Ondansetron clinical pharmacokinetics. Clin Pharmacokinet 29:95-109

44. Kirvela M, Ali-Melkkila T, Kaila T, Iisalo E, Lindgren L (1993) Pharmacokinetics of glycopyrronium in uraemic patients. Br J Anaesth 71:437-439

45. Galbraith S, Fagan P, Perkins P, Lynch A, Booth S (2010) Does the use of a handheld fan improve chronic dyspnea? A randomized, controlled, crossover trial. J Pain Symptom Manag 39:831-838. https://doi.org/10.1016/j.jpainsymman.2009.09.024

46. Allard P, Lamontagne C, Bernard P, Tremblay C (1999) How effective are supplementary doses of opioids for dyspnea in terminally ill cancer patients? A randomized continuous sequential clinical trial. J Pain Symptom Manag 17:256-265. https://doi.org/10.1016/ S0885-3924(98)00157-2

47. Navigante AH, Cerchietti LCA, Castro MA, Lutteral MA, Cabalar ME (2006) Midazolam as adjunct therapy to morphine in the alleviation of severe dyspnea perception in patients with advanced cancer. J Pain Symptom Manag 31:38-47. https://doi.org/10. 1016/j.jpainsymman.2005.06.009

48. Gunal AI, Ozalp G, Yoldas TK, Gunal SY, Kirciman E, Celiker H (2004) Gabapentin therapy for pruritus in haemodialysis patients: a randomized, placebo-controlled, double-blind trial. Nephrol Dial Transplant 19:3137-3139. https://doi.org/10.1093/ndt/gfh496

49. Yue J, Jiao S, Xiao Y, Ren W, Zhao T, Meng J (2015) Comparison of pregabalin with ondansetron in treatment of uraemic pruritus in dialysis patients: a prospective, randomized, double-blind study. Int Urol Nephrol 47:161-167. https://doi.org/10.1007/s11255-0140795-x

50. Peer G, Kivity S, Agami O, Fireman E, Silverberg D, Blum M, Iaina A (1996) Randomised crossover trial of naltrexone in uraemic pruritus. Lancet 348:1552-1554. https://doi.org/10.1016/S01406736(96)04176-1

51. Pauli-Magnus C, Mikus G, Alscher DM, Kirschner T, Nagel W, Gugeler N, Risler T, Berger ED, Kuhlmann U, Mettang T (2000) Naltrexone does not relieve uremic pruritus: results of a randomized, double-blind, placebo-controlled crossover study. J Am Soc Nephrol 11:514-519

52. Daly BM, Shuster S (2000) Antipruritic action of thalidomide. Acta Derm Venereol 80:24-25

53. Eriksson T, Höglund P, Turesson I, Waage A, Don BR, Vu J, Scheffler M, Kaysen G (2003) Pharmacokinetics of thalidomide in patients with impaired renal function and while on and off dialysis. J Pharm Pharmacol 55:1701-1706

Answers 1.b;2. d; 3. c; 4. d; 5. d

Publisher's note Springer Nature remains neutral with regard to jurisdictional claims in published maps and institutional affiliations. 